\title{
NEUROLOGIC CYTOMEGALOVIRUS COMPLICATIONS IN PATIENTS WITH AIDS: RETROSPECTIVE REVIEW OF 13 CASES AND REVIEW OF THE LITERATURE
}

Camila ALMEIDA SILVA(1), Augusto C. PENAlVA DE OLIVEIRA(2,3), Lucy VILAS-BOAS(4), Maria Cristina D.S. FINK(4), Cláudio S. PANNUTI(4) \& José E. VIDAL $(2,5)$.

\begin{abstract}
SUMMARY
Neurological disorders caused by Cytomegalovirus (CMV) in patients with Acquired Immunodeficiency Syndrome (AIDS) are rarely reported in the Highly Active Antiretroviral Therapy (HAART) period. The objective of this study was to describe the main clinical and laboratory features of patients with CMV-related neurological complications in HIV-infected patients admitted to a referral center in São Paulo, Brazil. CMV disease requires the identification of the virus in the cerebrospinal fluid (CSF) using Polymerase Chain Reaction (PCR). Thirteen cases were identified between January, 2004 and December, 2008. The median age of patients was 38 years and nine (69\%) were men. At admission all patients were aware of their HIV status and only four (31\%) patients were on HAART. Patients who were not on antiretroviral therapy before admission received HAART while inpatients. CMV disease was the first AIDS-defining illness in eight (62\%) patients. The neurologic syndromes identified were diffuse encephalitis $(\mathrm{n}=7 ; 62 \%)$, polyradiculopathy $(\mathrm{n}=7 ; 54 \%)$, focal encephalitis (rhombencephalitis) $(\mathrm{n}=1 ; 8 \%)$, and ventriculo-encephalitis $(\mathrm{n}=1 ; 8 \%)$. Seven (54\%) patients presented extra-neural CMV disease and four (31\%) had retinitis. The median of CD4+ T-cell count was 13 cells/ $\mu \mathrm{L}$ (range: 1-124 cells/ $\mu \mathrm{L}$ ). Overall in-hospital mortality was 38\%. Eight patients used ganciclovir or foscarnet (in-hospital mortality: $50 \%$ ) and five patients used ganciclovir and foscarnet (in-hospital mortality: 20\%). None of the patients fulfilled the diagnosis criteria of immune reconstitution inflammatory syndrome. Four patients were lost to follow-up, and three patients presented immune recovery and discontinued secondary prophylaxis. Although infrequent, distinct neurological syndromes caused by CMV continue to cause high mortality among AIDS patients. Survival depends upon the use of effective antiviral therapy against CMV and the early introduction of HAART.
\end{abstract}

KEYWORDS: Human immunodeficiency virus; AIDS; Cytomegalovirus; Encephalitis; Polyradiculopathy.

\section{INTRODUCTION}

Highly Active Antiretroviral Therapy (HAART) has decreased the morbidity and mortality rate in Human immunodeficiency virus (HIV) patients with complications caused by Cytomegalovirus (CMV) $)^{5,18}$. Reactivation of the infection in Acquired Immunodeficiency Syndrome (AIDS) patients usually presents itself as retinitis or gastrointestinal involvement, whereas other neurologic syndromes are considerably less common ${ }^{5}$. In this area, two Brazilian studies showed that these complications are rare in the HAART period ${ }^{28,33}$. However, neurologic complications caused by CMV continue to occur for several reasons: 1) patients fail to use HAART, either because they are not in care or are non-adherent; 2) antiretroviral resistance; and 3) late HIV diagnosis (late presenters). Furthermore, the individual clinical impact of neurological disorders caused by CMV continues to be relevant. In this retrospective study, we report on a case series of HIV-infected patients with encephalitis, rhombencephalitis, ventriculoencephalitis, and/or polyradiculopathy secondary to CMV, and discuss diagnosis and therapeutic issues.

\section{PATIENTS AND METHODS}

We performed a retrospective study between January, 2004 and December, 2008. All adult HIV-infected patients admitted to the Instituto de Infectologia Emílio Ribas, São Paulo, Brazil, with a neurological disorder caused by CMV were included. CMV disease required the identification of the virus in the cerebrospinal fluid (CSF) using Polymerase Chain Reaction (PCR). For this purpose, we reviewed the records of the Laboratory of Virology at the Instituto de Medicina Tropical de São Paulo, where the CSF-PCR for the diagnosis of CMV infection of the patients at our institution is performed. We reviewed the clinical charts of all patients. This study was approved by the Institutional Review Board of the Instituto de Infectologia Emilio Ribas.

Clinical syndromes were defined as follows: 1) diffuse encephalitis: progressive encephalopathy or dementia syndrome; 2) focal encephalitis (rhombencephalitis): focal signs indicative of brainstem and/or cerebella involvement; 3) ventriculo-encephalitis: lethargy or mental confusion,

(1) Departamento de Infectologia, Instituto de Infectologia Emílio Ribas, São Paulo, SP, Brasil

(2) Departamento de Neurologia, Instituto de Infectologia Emílio Ribas, São Paulo, SP, Brasil.

(3) Unidade de Pesquisa Clínica em Retroviroses Humanas, Universidade de Campinas, São Paulo, SP, Brasil.

(4) Laboratório de Virologia, Instituto de Medicina Tropical de São Paulo, Universidade de São Paulo, São Paulo, SP, Brasil.

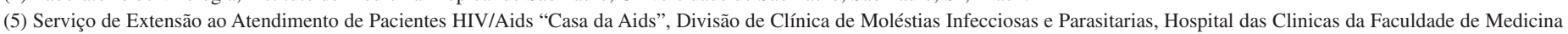
da Universidade de São Paulo, São Paulo, SP, Brasil.

Correspondence to: José E. Vidal, Serviço de Neurologia, Instituto de Infectologia Emílio Ribas, Av. Dr. Arnaldo 165, 01246-900 São Paulo, SP, Brasil. E-mail: josevibe@ gmail.com 


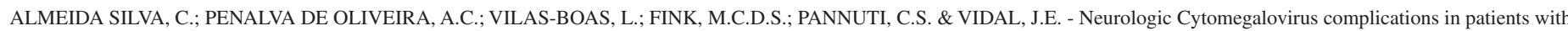
AIDS: retrospective review of 13 cases and review of the literature. Rev. Inst. Med. Trop. Sao Paulo, 52(6): 305-10, 2010.

nystagmus, and unilateral or bilateral cranial nerve palsies; and 4) polyradiculopathy: progressive ascending bilateral weakness, distal sensory loss, arreflexia, and bladder and/or anal sphincter dysfunction. These definitions were adapted from studies published elsewhere ${ }^{17,27,29}$.

The CMV DNA amplification was performed using a standard PCR technique that amplified the $\mathrm{gB}$ gene, according with $\mathrm{CHOU}$ \& DENNISON ${ }^{6}$. HIV infection was documented by HIV-1 antibody enzyme-linked immunosorbent assay (ELISA) and Western blot analysis.

Median was compared using Wilcoxon rank sum test with continuity correction.

\section{RESULTS}

A total of $13 \mathrm{HIV}$-infected patients with neurological complications secondary to CMV were included. All cases with positive CSF PCR for CMV DNA presented clinical manifestation compatible with CMV disease (no false positive cases were identified). Table 1 shows the main clinical and laboratory features of our patients. Nine (69\%) were men and median age was 38 years (range: $28-58$ years). All patients were aware of their HIV status before the admission. The median diagnosis of HIV infection was 36 months (range: 1-216 months). In eight (62\%) patients, CMV disease was the first AIDS-defining illness. None of the patients presented histories of CMV disease but all of them had documented history of CMV infection with antibody detection (CMV IgG). Four (31\%) patients were on HAART at admission: two had extensive multidrug resistance and two reported irregular treatment. The clinical syndromes identified were: encephalitis $(n=7,54 \%)$, polyradiculopathy $(\mathrm{n}=7,54 \%)$, focal encephalitis (rhombencephalitis) $(\mathrm{n}=1,8 \%)$, and ventriculo-encephalitis $(\mathrm{n}=1,8 \%)$. Three $(23 \%)$ patients presented polyradiculopathy and encephalitis simultaneously. Seven (54\%) patients presented extra-neural CMV disease, including four (31\%) with retinitis, although ophthalmoscopic examination was performed in all cases. In only one case the diagnosis of CMV neurologic complication was considered in the emergency room of our institution.

The median of CD4+ T-cell count was 13 cells/ $\mu \mathrm{L}$ (range: $1-124$ cells/ $\mu \mathrm{L}$ ). In CSF, the total leukocyte count median was 3 cells $/ \mathrm{mm}^{3}$ (range: $1-3150$ cells $/ \mathrm{mm}^{3}$ ), glucose median was $50 \mathrm{mg} / \mathrm{dL}$ (range: $10-89 \mathrm{mg}$ / $\mathrm{dL}$ ), and protein median was $113 \mathrm{mg} / \mathrm{dL}$ (range: $25-914 \mathrm{mg} / \mathrm{dL}$ ). Normal CSF was observed in only one case. The quantitative pp65 antigenemia assay median was 10 positive cells per 400,000 neutrophils (range: 0-96 positive cells per 400,000 neuthophils).

Brain computed tomography (CT) imaging showed hypodense bifrontal areas in the white matter of cases 7,9,10. Magnetic resonance imaging (MRI) was performed in four patients: cases 9 and 10 showed hyperintense bi-frontal areas on T2-weighted and fluid attenuated inversion recovery images (FLAIR), confirming the CT findings;

Table 1

Main clinical and laboratory characteristics of $13 \mathrm{HIV}$-infected patients with neurologic Cytomegalovirus complications

\begin{tabular}{|c|c|c|c|c|c|c|c|c|}
\hline Case & Age/Sex & $\begin{array}{l}\text { AIDS-defining } \\
\text { condition }\end{array}$ & Clinical syndrome & $\begin{array}{l}\text { Extra-neural } \\
\text { CMV disease }\end{array}$ & $\mathrm{CD}^{+}{ }^{+}$cell $/ \mu \mathrm{L}$ & pp65 antigen & Treatment & $\begin{array}{l}\text { In-hospital } \\
\text { outcome }\end{array}$ \\
\hline 1 & $36 / \mathrm{M}$ & Toxoplasmosis & Polyradiculopathy & Not & 2 & 56 cells & $\begin{array}{c}\text { Ganciclovir }+ \\
\text { Foscarnet }\end{array}$ & Alive \\
\hline 2 & $41 / \mathrm{M}$ & Toxoplasmosis & Polyradiculopathy & Not & 46 & 72 cells & Ganciclovir & Death \\
\hline 3 & $30 / \mathrm{M}$ & Neurologic CMV & Polyradiculopathy & Colitis & 54 & NA & Ganciclovir & Death \\
\hline 4 & $29 / \mathrm{M}$ & Neurologic CMV & $\begin{array}{c}\text { Diffuse encephalitis + } \\
\text { Polyradiculopathy }\end{array}$ & Not & 124 & 96 cells & $\begin{array}{l}\text { Ganciclovir }+ \\
\text { Foscarnet }\end{array}$ & Alive \\
\hline 5 & $29 / \mathrm{M}$ & Neurologic CMV & $\begin{array}{c}\text { Encephalitis + } \\
\text { Polyradiculopathy }\end{array}$ & Not & 2 & NA & Ganciclovir & Death \\
\hline 6 & $38 / \mathrm{F}$ & Neurologic CMV & Diffuse encephalitis & Not & 37 & NA & Ganciclovir & Alive \\
\hline 7 & $58 / \mathrm{F}$ & Neurologic CMV & Diffuse encephalitis & Not & 14 & Negative & Ganciclovir & Alive \\
\hline 8 & 44 / F & Neurologic CMV & Ventrículo-encephalitis & Retinitis & 13 & NA & $\begin{array}{l}\text { Ganciclovir }+ \\
\text { Foscarnet }\end{array}$ & Alive \\
\hline 9 & $45 / \mathrm{M}$ & Toxoplasmosis & Diffuse encephalitis & $\begin{array}{l}\text { Retinitis, } \\
\text { Esophagitis }\end{array}$ & 1 & NA & Ganciclovir & Death \\
\hline 10 & $58 / \mathrm{M}$ & Neurologic CMV & Diffuse encephalitis & Retinitis & 9 & Negative & Ganciclovir & Alive \\
\hline 11 & $53 / \mathrm{F}$ & $\begin{array}{l}\text { Wasting } \\
\text { syndrome }\end{array}$ & $\begin{array}{c}\text { Diffuse encephalitis + } \\
\text { Polyradiculopathy }\end{array}$ & Pneumonitis & 12 & 11 cells & Foscarnet & Alive \\
\hline 12 & $28 / \mathrm{M}$ & Neurologic CMV & Myeloradiculopathy & Gastric ulcer & 14 & 9 cells & $\begin{array}{l}\text { Ganciclovir }+ \\
\text { Foscarnet }\end{array}$ & Alive \\
\hline 13 & $34 / \mathrm{M}$ & Toxoplasmosis & $\begin{array}{l}\text { Focal encephalitis } \\
\text { (Rhombencephalitis) }\end{array}$ & Retinitis & 12 & Negative & $\begin{array}{l}\text { Ganciclovir }+ \\
\text { Foscarnet }\end{array}$ & Death \\
\hline
\end{tabular}

$\mathrm{M}=$ male; $\mathrm{F}=$ female; $\mathrm{NA}=$ not available 


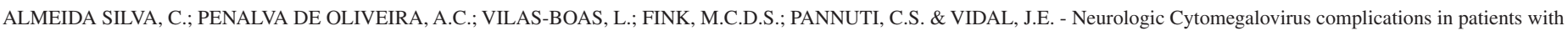
AIDS: retrospective review of 13 cases and review of the literature. Rev. Inst. Med. Trop. Sao Paulo, 52(6): 305-10, 2010.

case 8 showed hyperintense periventricular areas on T2-weighted images, FLAIR and enhancement in this topography after gadolinium administration; and the case 13 showed one hyperintense image on T2weighted and FLAIR in the brainstem.

Median time of hospitalization was 60 days (range: 13-111 days) Median time to anti-Cytomegalovirus treatment was 28 (range: 6-60) days. Median use time of these drugs was 28 (range: 6-56) days and 30 (range: 16-60) days in patients with monotherapy and combination therapy, respectively. Five (63\%) of eight patients that used ganciclovir or foscarnet died and one (20\%) of five patients that used ganciclovir plus foscarnet died. However, this difference was not significant $(p=0.56)$. The decision to use combination therapy considered the hematological and renal function of the patients and the neurologic status. Thus, the patients with more severe disease received ganciclovir and foscarnet. After reviewing the history of treatment, all patients were on HAART within the first two weeks of admission. The two patients with triple-class resistance received a non-suppressive regimen.

Overall in-hospital mortality was 38\% (5/13): three as a result of nosocomial pneumonia and two secondary to CMV encephalitis. Autopsy was not performed in any case. One patient died due to acute renal failure after six months of discharge, when he has been receiving maintenance therapy with foscarnet and taking tenofovir, lamivudine, and efavirenz $(\mathrm{CD} 4=326$ cells $/ \mu \mathrm{L} ; \mathrm{VL}<50$ copies $/ \mathrm{mL})$. None of the patients fulfilled the diagnosis criteria of immune reconstitution inflammatory syndrome (IRIS) ${ }^{32}$. Nevertheless, this complication could not be completely overlooked in all cases. One year after discharge, four patients had at least one outpatient evaluation and three were lost to follow-up. Among the three patients available one year after the diagnosis, two received ganciclovir plus foscarnet in the induction phase and the other one received ganciclovir. However, all these three patients received secondary prophylaxis with ganciclovir. The CD4+ T-cell count median of the three available patients was 189 cells $/ \mu \mathrm{L}$ (range: $180-214$ cells/ $\mu \mathrm{L}$ ), all presented HIV-1 viral $<50$ copies $/ \mathrm{mL}$, and adequate use of HAART. In all cases, CMV therapy was discontinued after CD4+ T cell count exceeded 100 cells/ $\mu \mathrm{L}$ for six months.

Table 2 shows times from admission to diagnosis, admission to death, and diagnosis to death of our patients. The median time from admission to death was 68 days (range: 8-57 days). The median time from correct diagnosis to death was 44 days (range: 6-104 days). The median times from admission to diagnosis was 9.5 days (range: 5-25 days) among survivals and 23 days (range: 8-57 days) among deaths $(p=0.09)$.

\section{DISCUSSION}

We found that neurologic CMV complications, although uncommon, continue to cause important mortality in our setting. Of note, all patients were aware of their HIV infection status and most patients presented CMV disease as initial AIDS defining illness. A subset of patients obtained clinical and laboratory improvement and were alive one year after the diagnosis of neurologic CMV complication.

Retinitis is the most common manifestation of CMV infection in patients with AIDS and its diagnosis is usually clinical. However, the spectrum of neurologic CMV complications is broad and their diagnosis and treatment is more challenging. In the present study, similar to some
Table 2

Times from admission to diagnosis, admission to death, and diagnosis to death in 13 HIV-infected patients with neurologic cytomegalovirus complications

\begin{tabular}{lccc}
\hline Case & $\begin{array}{c}\text { Time from } \\
\text { admission } \\
\text { to diagnosis } \\
\text { (days) }\end{array}$ & $\begin{array}{c}\text { Time from } \\
\text { admission } \\
\text { to death } \\
\text { (days) }\end{array}$ & $\begin{array}{c}\text { Time from } \\
\text { diagnosis } \\
\text { to death } \\
\text { (days) }\end{array}$ \\
\hline 1 & 5 & Alive & Alive \\
2 & 14 & 118 & 104 \\
3 & 23 & 68 & 45 \\
4 & 11 & Alive & Alive \\
5 & 57 & 101 & 44 \\
6 & 25 & Alive & Alive \\
7 & 15 & Alive & Alive \\
8 & 9 & Alive & Alive \\
9 & 8 & 14 & 6 \\
10 & 10 & Alive & Alive \\
11 & 7 & Alive & Alive \\
12 & 7 & Alive & Alive \\
13 & 28 & 37 & 9 \\
\hline
\end{tabular}

reports of the pre HAART period ${ }^{2,26}$, approximately $30 \%$ of patients with neurologic CMV complications presented concomitant CMV retinitis. For this reason, routine ophthalmologic evaluation should be performed in all these patients. However, most patients will have simultaneous involvement of other organs at autopsy ${ }^{11}$.

Clinical studies performed in developed countries in the HAART era reported a prevalence of CMV encephalitis $<2 \%{ }^{21}$. Similar figures have been reported in hospital-based studies in Brazil ${ }^{28,33}$.

As in the pre-HAART period, all patients included in this study presented with very low CD4+ T cell counts. Most ( 70\%) had not been using HAART. This picture reflects failures in HIV therapy, particularly in Brazil, a developing country with a universal and free access antiretroviral program. It is important to reinforce that these serious neurologic CMV complications are best prevented by using HAART to maintain the CD4+ T cell counts $>100$ cells $/ \mu \mathrm{L}^{5}$.

Neurologic CMV complication was the first AIDS-defining condition in $\sim 60 \%$ of our patients. Conversely, this figure was only $\sim 10 \%$ in the pre HAART period ${ }^{2,26}$. This finding suggests that CMV should be included in the differential diagnosis of neurologic complaints in AIDS patients with severe immunosuppression, and without history of previous AIDS-defining conditions.

Presumptive clinical diagnosis of some neurologic CMV syndromes can be made on the basis of a combination of signs and symptoms, imaging, and CSF findings ${ }^{24,25}$. Distinct clinical syndromes such as ventriculo-encephalitis and polyradiculopathy were well described in classical studies of the pre HAART period. However, neurologic 


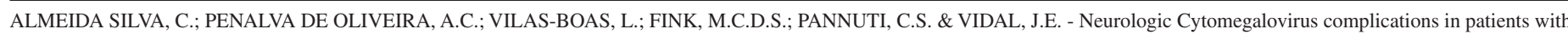
AIDS: retrospective review of 13 cases and review of the literature. Rev. Inst. Med. Trop. Sao Paulo, 52(6): 305-10, 2010

complications due to CMV are not usually considered in the emergency room, as was observed in the present study. In contrast, CMV encephalitis may be difficult to differentiate from those of HIV encephalitis.

A neuropathology study of HIV-infected patients reported $28(17 \%)$ cases of CMV encephalitis, most of them with pre-mortem diagnosis of HIV dementia, showing that CMV has been underestimated as a cause of neurocognitve disorders ${ }^{15}$. Our results reinforce the importance of in vivo diagnosis of CMV encephalitis and the need to include this etiology in the differential diagnosis of patients with clinical suspicion of HIV dementia and severe immunosuppression. On the other hand, encephalitis has been described even in patients already receiving ganciclovir ${ }^{23}$.

CMV polyradiculopathy causes a Guillain-Barré-like syndrome characterized by urinary retention and progressive bilateral leg weakness. The differential diagnosis in HIV-infected patients includes other opportunistic infections (tuberculosis, herpes simplex virus - HSV - type 2 , varicella-zoster virus, and toxoplasmosis), syphilis, and lymphoma ${ }^{26}$.

Rhombencephalitis is an unusual manifestation of CMV disease and when isolated its diagnosis is more difficult. Their main differential diagnosis includes HSV-1, tuberculosis and lymphoma ${ }^{27}$.

Neurologic CMV complications usually occur in patients with very low $\mathrm{CD} 4$ cell counts $(<50$ cells $/ \mu \mathrm{L})$ and are often simultaneously present at other sites (retina, gastrointestinal tracts, blood, etc) ${ }^{20}$. However, 6/13 patients of the present series did not present extra-neural CMV diseases, except by the presence of pp65 antigenemia in three of them. Antigenemia was not performed in five patients; of those, two had retinitis, one had colitis and the other two had not any extra-neurologic disease. The presence of CMV viremia is an important factor but it is not required in the setting of "compartmentalized infections" such as colitis, esophagitis or neurologic disease. The determination of pp65 antigenemia depends on a technician and the absence of antigenemia is not equal to the absence of viremia, since CMV-PCR in blood samples is a more sensitive method. CMV complications restricted to the nervous system should be considered in the adequate clinical and immunological context. In this setting, minimally invasive diagnosis using CSF-PCR for CMV DNA is particularly useful. This tool showed 62-100\% sensitivity and $89-100 \%$ of specificity in CMV encephalitis and polyradiculopathy ${ }^{29}$, and present positive and negative predictive values ranged between 86 $95 \%$ and $95-98 \%$, respectively ${ }^{7-9}$.

Although neurologic CMV complications are unusual, it is likely that they are under-diagnosed or -reported in developing countries because of difficult access to reference centers with diagnostic support, including molecular diagnosis and neuroimaging. The results of the present study suggest that CMV might be more frequently diagnosed when appropriate diagnostic procedures can be employed. Furthermore, a timely diagnosis and prompt treatment is critical for an adequate clinical response. However, the absence of specific treatment in most low- and middle-income countries constitutes an unsolved problem that limits the outcome for these patients.

Examination of CSF is non-specific for the diagnosis of CMV encephalitis due to their variable profile. CMV encephalitis rarely causes pleocytosis; if a pleocytosis occurs it is usually low grade and consists predominantly of lymphocytes and monocytes. On the other hand, CSF abnormalities in patients with CMV polyradiculopathy can mimic the pattern of acute bacterial meningitis, including a pleocytosis with polymorphonuclear leucocyte preponderance, a raised protein concentration and hypoglycorrhachia or a reduced CSF:plasma glucose ratio ${ }^{24,25}$. Some studies reported $50-76 \%$ of patients with CMV poliradiculopathy and "typical" polymorphonuclear preponderant pleocytosis ${ }^{21}$. In our study we confirm a broad spectrum of CSF patterns in CMV polyradiculopathy.

In the pre HAART period, the overall prognosis of neurologic CMV complications was poor, independent of treatment, with survival of one to four months $s^{2,3,11,26}$. For example, in a retrospective study of 103 cases published with CMV polyradiculopathy, the mean survival time for untreated and treated patients with ganciclovir was 5.4 and 14.6 weeks, respectively ${ }^{1}$. In contrast, in the present study, the use of HAART along with the specific treatment for CMV resulted in an effective immune recovery that improved the outcome of a subset of patients.

Both ganciclovir and foscarnet are known to penetrate well in to the CSF. For example, there are reports that CSF ganciclovir concentrations were $24-67 \%$ of the concurrent plasma concentrations and foscarnet was reported to distribute to the CSF in a concentration varying from 13 to $68 \%$ of the concomitant plasma concentration ${ }^{18}$. There is no data about cidofovir CSF concentrations as a percentage of plasma concentration. Nevertheless, cidofovir CSF penetration is low ${ }^{12}$.

The efficacies and toxicities of approved treatments for CMV retinitis have been established by randomized prospective trials. In contrast, there have been no prospective randomized trials of treatment for CMV neurologic disease ${ }^{5}$. The largest series published was an open noncomparative multicentre study of 31 patients with CMV encephalitis of myelitis, $60 \%$ of them with previous $\mathrm{CMV}^{2}$. This study was performed in the pre HAART period, and all patients received ganciclovir plus foscarnet by a media of six weeks. Approximately $75 \%$ of patients presented clinical improvement or stabilization and $32 \%$ of patients discontinued one of the two drugs because of side-effects. The median survival time was only three months.

Treatment recommendations to neurologic CMV complications are diverse, but most suggest ganciclovir, foscarnet or both agents in combination $^{9,13,14,17,19,27,29,34}$ and highlight that initiating therapy promptly is critical for an optimal clinical response. Some authors recommend combination therapy in all case ${ }^{11,20}$ or in patients who have received prior antiviral therapy for CMV or in patients with disease progression under monotherapy ${ }^{22,34}$. In the present study we observed that most patients with combination therapy were discharged alive, but it was not significantly higher compared with those receiving monotherapy. Nevertheless, the choice between one or two anti-CMV drugs was arbitrary, but usually combination treatment was indicated in patients with more severe neurologic disease.

Although there is few data that support the use of cidofovir in the treatment of CMV-related neurological disorders ${ }^{31}$, its use could be considered in those failing or intolerant of ganciclovir and foscarnet therapy.

The duration of induction treatment is variable in the literature (3-8 weeks $)^{11,27,29}$. We prefer at least four weeks, but in some cases a response 


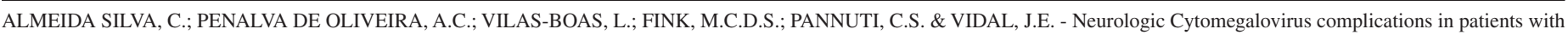
AIDS: retrospective review of 13 cases and review of the literature. Rev. Inst. Med. Trop. Sao Paulo, 52(6): 305-10, 2010.

Table 3

Therapeutic regimens for neurologic Cytomegalovirus complications*

\begin{tabular}{|c|c|c|c|}
\hline Type of therapy & Patients with renal dysfuncion & $\begin{array}{l}\text { Patients with severe neutropenia or } \\
\text { thrombocytopenia }\end{array}$ & $\begin{array}{l}\text { Patients previously treated with } \\
\text { antivirals for CMV or with disease } \\
\text { progression }\end{array}$ \\
\hline Induction therapy & Ganciclovir $5 \mathrm{mg} / \mathrm{kg}$ IV every $12 \mathrm{hr}$ & Foscarnet $90 \mathrm{mg} / \mathrm{kg}$ IV every $12 \mathrm{hr}$ & $\begin{array}{l}\text { Ganciclovir } 5 \mathrm{mg} / \mathrm{kg} \mathrm{IV} \text { + foscarnet } \\
90 \mathrm{mg} / \mathrm{kg} \text { IV every } 12 \mathrm{hr}\end{array}$ \\
\hline Maintenance therapy & $\begin{array}{l}\text { Valganciclovir } 900 \mathrm{mg} / \text { day PO } \\
\text { every } 12 \mathrm{hr} \text { or ganciclovir } \\
5 \mathrm{mg} / \mathrm{kg} / \text { day IV }\end{array}$ & Foscarnet $90-120 \mathrm{mg} / \mathrm{kg} /$ day IV & $\begin{array}{l}\text { Valganciclovir } 900 \mathrm{mg} / \text { day PO } \\
\text { every } 12 \mathrm{hr} \text { or ganciclovir } 5 \mathrm{mg} / \mathrm{kg} / \\
\text { day IV + foscarnet } 90-120 \mathrm{mg} / \mathrm{kg} / \\
\text { day IV }\end{array}$ \\
\hline
\end{tabular}

* Adapted from References 2,4,5,17,20,22.

will be noted after this period. A close clinical follow up and CSF-PCR for CMV DNA can guide the optimal duration of treatment on an individual basis. However, the retrospective nature of our study and the small number of cases evaluated precludes any definitive recommendation about the optimal treatment of neurologic CMV complications in AIDS patients.

Maintenance therapy options include one (valganciclovir, ganciclovir or foscarnet) or two drugs (valganciclovir or ganciclovir plus foscarnet). Maintenance monotherapy seems to be particularly advisable in patients without previous use of ganciclovir where the possibility to obtain an adequate immune reconstitution due to HAART is a realistic one. Although may not be readily available in most developing countries and most data was extrapolated from Cytomegalovirus retinitis, the use of valganciclovir (an orally administered prodrug of ganciclovir) seem to be the preferred regimen to maintenance ${ }^{4}$. The use of maintenance therapy with foscarnet is feasible but cumbersome since it requires a permanent line for its administration and frequent monitoring of electrolytes and kidney function. Although the optimal time to discontinue maintenance therapy is unknown, some authors suggest that can be safely discontinued in patients with inactive disease and sustained immune reconstitution $(C D 4+T$ cells count $>100$ cells $/ \mu \mathrm{L}$ for 3-6 months on HAART $)^{17,20,22}$. Three of our patients discontinued maintenance therapy after six months with CD4+T cell count $>100$ cells $/ \mu \mathrm{L}$. Recommended therapy regimens are shown in Table 3.

In contrast to cytomegalovirus immune recovery uveitis ${ }^{4}$, IRIS seems to be very rare in patients with neurologic cytomegalovirus complications. In accordance with this, none of the included patients in this study fulfilled the diagnosis criteria of IRIS ${ }^{32}$.

In conclusion, neurologic CMV complications are uncommon but distinct diseases and continue to cause high mortality in our setting. CSF-PCR for detection of CMV DNA permits a timely diagnosis. Although there is no a definitive choice treatment, the use of specific antivirals associated to HAART improved the outcome of a subset of patients.

\section{RESUMO}

\section{Complicações neurológicas causadas pelo Citomegalovírus em pacientes com aids: estudo retrospectivo de 13 casos e revisão da literatura}

As complicações neurológicas causadas pelo Citomegalovírus
(CMV) em pacientes com aids são raramente relatadas na era HAART. O objetivo deste estudo foi descrever as principais características clínicas e laboratoriais de pacientes com complicações neurológicas associadas ao CMV em pacientes com aids admitidos em centro de referência em Sao Paulo, Brasil. A doença citomegálica precisou da identificação do vírus no líquor mediante a reação em cadeia da polimerase (PCR). Treze casos foram identificados entre janeiro de 2004 e dezembro de 2008. A mediana da idade foi 38 anos e nove (69\%) eram homens. Na admissão, todos os pacientes sabiam do seu status sorológico para o HIV e apenas quatro (31\%) pacientes usavam HAART. A doença citomegálica foi a primeira doença definidora de aids em oito (62\%) pacientes. As síndromes neurológicas identificadas foram: encefalite difusa $(\mathrm{n}=7 ; 62 \%)$, polirradiculopatia $(\mathrm{n}=7 ; 54 \%)$, encefalite focal (romboencefalite) $(\mathrm{n}=1 ; 8 \%)$, e ventrículo-encefalite $(\mathrm{n}=1 ; 8 \%)$. Sete $(54 \%)$ pacientes apresentaram doença citomegálica fora do sistema nervoso e quatro (31\%) tiveram retinite. A mediana da contagem de células CD4+ foi 13 células/ $\mu \mathrm{L}$. A mortalidade global durante a internação foi $38 \%$. Oito pacientes usaram ganciclovir ou foscarnet (mortalidade: $50 \%$ ) e cinco pacientes usaram ganciclovir e foscarnet (mortalidade: 20\%). Nenhum paciente apresentou critérios diagnósticos da síndrome inflamatória de reconstituição imunológica. Quatro pacientes foram perdidos do acompanhamento ambulatorial e três pacientes apresentaram reconstituição imunológica e descontinuaram as profilaxias secundárias. Embora raras, as particulares síndromes neurológicas causadas pelo CMV continuam causando elevada mortalidade em pacientes com aids. A sobrevida depende do uso de terapia antiviral efetiva contra o CMV e a introdução oportuna do HAART.

\section{ACKNOWLEDGEMENTS}

We would like to thank David Clifford, Washington University School of Medicine, St. Louis, USA, and two anonymous referees for valuable comments.

\section{REFERENCES}

1. Anders HJ, Goebel FD. Cytomegalovirus polyradiculopathy in patients with AIDS. Clin Infect Dis. 1998;27:345-52.

2. Anduze-Faris BM, Fillet AM, Gozlan J, Lancar R, Boukli N, Gasnault J, et al. Induction and maintenance therapy of cytomegalovirus central nervous system infection in HIV-infected patients. AIDS. 2000;14:517-24.

3. Arribas JR, Storch GA, Clifford DB, Tselis AC. Cytomegalovirus encephalitis. Ann Intern Med. 1996;125:577-87. 
ALMEIDA SILVA, C.; PENALVA DE OLIVEIRA, A.C.; VILAS-BOAS, L.; FINK, M.C.D.S.; PANNUTI, C.S. \& VIDAL, J.E. - Neurologic Cytomegalovirus complications in patients with AIDS: retrospective review of 13 cases and review of the literature. Rev. Inst. Med. Trop. Sao Paulo, 52(6): 305-10, 2010.

4. Bartlett JG, Gallant JE, Pham PA. Medical management of HIV infection: 2009-2010. $15^{\text {th }}$ ed. Durham: Knowledge Source Solutions; 2009. 569p.

5. Centers for Disease Control and Prevention. Guidelines for prevention and treatment of opportunistic infections in HIV-infected adults and adolescents. Recommendations from CDC, the National Institutes of Health, and HIV Medicine Association of the Infectious Diseases Society of America. MMWR Recomm Rep. 2009;58[RR4]:1-207.

6. Chou SW, Dennison KM. Analysis of interstrain variation in cytomegalovirus glycoprotein B sequences encoding neutralization-related epitopes. J Infect Dis. 1991;163:1229-34.

7. Cinque P, Vago L, Terreni MR, Brytting M, Marenzi R, Castagna A, et al. Diagnosis of Cytomegalovirus infection of the nervous system in AIDS by polymerase chain reaction analysis of cerebrospinal fluid. Scand J Infect Dis. 1995;99(Suppl. 1):92-4.

8. Cinque P, Baldanti F, Vago L, Terreni MR, Lillo F, Furione M, et al. Ganciclovir therapy for cytomegalovirus (CMV) infection of the central nervous system in AIDS patients: monitoring by CMV DNA detection in cerebrospinal fluid. J Infect Dis. 1995;171:1603-6.

9. Cinque P, Cleator GM, Weber T, Monteyne P, Sindic C, Gerna G, et al. Diagnosis and clinical management of neurological disorders caused by cytomegalovirus in AIDS patients. J Neurovirol. 1998;4:120-32.

10. Cinque P, Bossolasco S, Bestetti A, Sala S, Pierotti C, Lazzarin A. Molecular studies of cerebrospinal fluid in human immunodeficiency vírus type 1-associated opportunistic central nervous system diseases - an update. J Neurovirol. 2002;8(Suppl. 2):122-8.

11. Collazos J. Opportunistic infections of the CNS in patients with AIDS: diagnosis and management. CNS Drugs. 2003;17:869-87.

12. Cundy KC. Clinical pharmacokinetics of the antiviral nucleotide analogues cidofovir and adefovir. Clin Pharmacokinet. 1999;36:127-43.

13. Enting R, de Gans J, Reiss P, Jansen C, Portegies P. Ganciclovir/foscarnet for cytomegalovirus meningoencephalitis in AIDS. Lancet. 1992;340:559-60.

14. Fletcher CV, Balfour HH Jr. Evaluation of ganciclovir for cytomegalovirus disease. DICP. 1989;23:5-12.

15. Goplen AK, Liestol K, Dunlop O, Bruun JN, Maehlen J. Dementia in AIDS patients in Oslo: the role of HIV encephalitis and CMV encephalitis. Scand J Infect Dis. 2001;33:755-8

16. Gozlan J, Salord JM, Roullet E, Baudrimont M, Caburet F, Picard O, et al. Rapid detection of cytomegalovirus DNA in cerebrospinal fluid of AIDS patients with neurologic disorders. J Infect Dis. 1992;166:1416-21.

17. Griffiths P. Cytomegalovirus infection of the central nervous system. Herpes. 2004;11(Suppl. 2):95A-104A.

18. Kedhar SR, Jabs DA. Cytomegalovirus retinitis in the era of highly active antiretroviral therapy. Herpes. 2007;14:66-71.

19. Mamidi A, De Simone JA, Pomerantz RJ. Central nervous system infections in individuals with HIV-1 infection. J Neurovirol. 2002;8:158-67.
20. Manzardo C, Del Mar Ortega M, Sued O, García F, Moreno A, Miró JM. Central nervous system opportunistic infections in developed countries in the highly active antiretroviral therapy era. J Neurovirol. 2005;11(Suppl. 3):72-82.

21. Maschke M, Kastrup O, Esser S, Ross B, Hengge U, Hufnagel A. Incidence and prevalence of neurological disorders associated with HIV since the introduction of highly active antiretroviral therapy. J Neurol Neurosurg Psychiatry. 2000;69:376-80.

22. Maschke M, Kastrup O, Diener HC. CNS manifestations of cytomegalovirus infections. CSN Drugs. 2002;16:303-15.

23. Mastroianni CM, Ciardi M, Folgori F, Sebastiani G, Vullo V, Delia S, et al. Cytomegalovirus encephalitis in two patients with AIDS receiving ganciclovir for cytomegalovirus retinitis. J Infect. 1994;29:331-7.

24. McCutchan JA. Cytomegalovirus infections of the nervous system in patients with AIDS Clin Infect Dis. 1995;20:747-54

25. McCutchan JA. Clinical impact of Cytomegalovirus infections of the nervous system in patients with AIDS. Clin Infect Dis. 1995;21(Suppl. 2): S196-201.

26. Miller RF, Fox JD, Thomas P, Waite JC, Sharvell Y, Gazzard BG, et al. Acute lumbosacral polyradiculopathy due to cytomegalovirus in advanced HIV disease: CSF findings in 17 patients. J Neurol Neurosurg Psychiatry. 1996;61:456-60.

27. Moulignier A. Atteintes du systéme nerveux central et infection par le VIH-1. Rev Neurol (Paris). 2006;162:22-42.

28. Oliveira JF, Greco DB, Oliveira GC, Christo PP, Guimaraes MD, Oliveira RC Neurological disease in HIV-infected patients in the era of highly active antiretroviral treatment: a Brazilian experience. Rev Soc Bras Med Trop. 2006;39:146-51.

29. Portegies P, Solod L, Cinque P, Chaudhuri A, Begovac J, Everall I, et al. Guidelines for the diagnosis and management of neurological complications of HIV infection. Eur J Neurol. 2004;11:297-304.

30. Sacktor $\mathrm{N}$. The epidemiology of human immunodeficiency virus-associated neurological disease in the era of highly active antiretroviral therapy. J Neurovirol. 2002;8(Suppl. 2):115-21

31. Sadler M, Morris-Jones S, Nelson, M, Gazzard, BG. Successful treatment of cytomegalovirus encephalitis in an AIDS patient using cidofovir. AIDS. 1997;11:1293-4

32. Shelburne SA, Montes M, Hamill RJ. Immune reconstitution inflammatory syndrome: more answers, more questions. J Antimicrob Chemother. 2006;57:167-70.

33. Vidal JE, Penalva de Oliveira AC, Fink MC, Pannuti CS, Trujillo JR. Aids-related progressive multifocal leukoencephalopathy: a retrospective study in a referral center in Sao Paulo, Brazil. Rev Inst Med Trop Sao Paulo. 2008;50:209-12.

34. Whitley RJ, Jacobson MA, Friedberg DN, Holland GN, Jabs DA, Dieterich DT, et al. Guidelines for the treatment of cytomegalovirus diseases in patients with AIDS in the era of potent antirretroiral therapy. Arch Intern Med. 1998;158:957-69.

Received: 29 January 2010

Accepted: 8 October 2010 